\title{
MENINGKATKAN KOMPETENSI MENGGAMBAR DESAIN POSTER MELALUI METODE DEMONSTRASI PADA SISWA KELAS XI DKV SMK NEGERI PACITAN TAHUN PELAJARAN 2012/2013
}

\author{
Paulus Sunarno \\ SMK NEGERI PACITAN
}

\begin{abstract}
Abstrak
Penelitian tindakan kelas ini bertujuan untuk mengetahui proses pembelajaran membuat desain poster dan untuk mengetahui sejauhmana metode demonstrasi dapat meningkatkan kompetensi menggambar desain poster pada siswa kelas XI program studi DKV SMK Negeri Pacitan. Penelitian tindakan kelas (PTK) ini menggunakan dua siklus. Dari hasil penelitian yang telah dilaksanakan setelah menggunakan metode demonstrasi, kompetensi menggambar desain poster pada siswa dapat meningkat secara signifikan yang dibuktikan dari hasil karya desain yang sudah sesuai dengan standar penilaian. Pada siklus 1, penilaian karya desain poster belum menunjukkan karya yang sesuai dengan kriteria penilaian dari berbagai unsur sehingga diperlukan suatu metode pembelajaran untuk meningkatkan kemampuan desain poster tersebut.Nilai rata-rata prestasi belajar siswa adalah 74,6 dan ketuntasan belajar mencapai $40 \%$ atau ada 9 siswa dari 22 siswa yang sudah tuntas belajar. Hasil ini menunjukkan bahwa pada siklus 1 ini ketuntasan belajar secara klasikal belum memenuhi standar nilai KKM yaitu 75 untuk mata pelajaran produktif. Pada siklus 2, kemampuan siswa dalam membuat desain poster dengan berbagai tema memlalui metode demonstrasi sudah menunjukkan peningkatan yang sangat memuaskan baik dilihat dari unsur komposisi, tata letak, pewarnaan maupun tipografi. Nilai rata-rata prestasi belajar siswa adalah 81,88 dan ketuntasan belajar mencapai $100 \%$ atau secara keseluruhan 22 siswa sudah tuntas belajar.
\end{abstract}

Kata Kunci : Kompetensi, Poster, Demonstrasi

\section{PENDAHULUAN}

Peraturan Menteri Pendidikan Nasional Nomor 41 Tahun 2007 tentang Standar Proses menyatakan bahwa standar proses meliputi perencanaan proses pembelajaran, pelaksanaan pembelajaran, penilaian hasil pembelajaran, dan pengawasan proses pembelajaran. Perencanaan proses pembelajaran terdiri atas silabus dan rencana pelaksanaan pembelajaran (RPP). Pada saat mengembangkan RPP guru harus mengacu pada silabus dan standar proses.

Setiap pendidik harus membuat RPP dan melaksanakan proses pembelajaran yang interaktif, inspiratif, menyenangkan, menantang, memotivasi peserta didik untuk berpartisifatif aktif serta memberikan ruang yang cukup bagi prakarsa, kreativitas, dan kemandirian sesuai bakat minat dan perkembangan fisik dan psikologis peserta didik. Untuk melaksanakan proses pembelajaran dalam rangka pencapaian kompetensi peserta didik diperlukan berbagai metode dan pendekatan yang sesuai dengan karakteristik setiap mata pelajaran. Berbagai model pembelajaran yang dikemukakan oleh para pakar pendidikan adalah varian yang menguntungkan guru dalam rangka pelaksanaan pemebelajaran yang menantang dan menyenangkan. Pemilihan dan penerapan strategi pembelajaran yang digunakan guru diakui telah mengalami pergeseran dari yang mengutamakan pemberian informasi (konsep-konsep) menuju kepada strategi yang mengutamakan keterampilan-keterampilan berpikir yang digunakan untuk memperoleh dan menggunakan konsep-konsep. Adanya perubahan pergeseran strategi ini otomatis peran guru harus berubah yaitu dari peran sebagai penyampai bahan pelajaran (transformator) ke peran sebagai fasilitator 
atau dari "teacher centered" ke "student centered".

Sebagai bagian dari Sistem Pendidikan Nasional, SMK merupakan pendidikan yang lebih mengutamakan kemampuan peserta didik untuk dapat bekerja sesuai dengan program keahlian masing-masing, beradaptasi di lingkungan kerja, atau dengan kata lain bahwa SMK berperan dalam menyiapkan peserta didik agar siap bekerja, baik bekerja secara mandiri maupun mengisi lowongan pekerjaan yang ada. Pembelajaran di sekolah menengah kejuruan menuntut siswa agar senantiasa trampil, tekun dan berjiwa mandiri. Siswa yang kompetetif akan menumbuhkan motivasi berkarya secara terus menerus sehingga akan menciptakan karya inovatif dan kreatif. Namun kondisi pembelajaran yang tidak kondusif akan sangat berpengaruh terhadap hasil belajar siswa. Oleh karena itu Guru harus dapat mengimplementasikan model pembelajaran yang tepat untuk mengatasi permasalahan pembelajaran di kelas. Metode pembelajaran bertujuan untuk menciptakan suasana belajar yang kondusif. Sejalan dengan pemikiran tersebut, kualitas pembelajaran ditentukan oleh tingkat partisipasi siswa di dalam proses belajar agar tercapai hasil pembelajaran yang berkualitas dan dapat meningkatkan motivasi siswa untuk berpartisipasi aktif dalam proses pembelajaran tersebut. (Djamarah, 2002).

Di SMK Negeri Pacitan pada program studi Desain Komunikasi Visual kelas XI tidak terlepas dari kondisi pembelajaran yang kurang menarik motivasi siswa untuk mengikuti pembelajaran secara optimal. Dari hasil pengamatan selama proses pembelajaran produktif pada program studi DKV materi menggambar desain poster didapatkan bahwa sebagian besar siswa belum memiliki kesiapan yang cukup untuk belajar di kelas, sehingga tidak dapat mengikuti secara aktif dalam proses pembelajaran. Hal tersebut terlihat dari aktivitas siswa dalam mengerjakan tugas membuat desain poster masih belum maksimal sehingga proses pembelajaran menjadi kurang menarik padahal metode mengajar yang digunakan oleh guru sudah diupayakan menerapkan model pembelajaran yang menyenangkan yaitu metode ceramah, diskusi, pemberian contoh karya dan pemberian tugas. Namun demikian dari hasil karya siswa yang sudah dievaluasi ternyata masih banyak yang belum memperoleh nilai KKM sebesar 75 . Sebagian besar karya siswa tersebut dikerjakan dengan tidak sungguh-sungguh dan masih perlu diperbaiki baik dari segi lay out, komposisi, keseimbangan dan pewarnaan sehingga dari berbagai unsur penilaian tidak memperoleh nilai yang cukup. (Bahan Ajar Dasar Kekriaan untuk SMK, 1998)

Pembelajaran produktif di kelas XI DKV belum berjalan secara maksimal. Hasil analisis lebih lanjut menunjukkan ternyata rendahnya perhatian dan motivasi belajar belajar siswa disebabkan guru tidak memberikan contoh secara langsung mengenai bagaimana langkah sistematis dalam membuat karya desain poster.

\section{METODE PENELITIAN}

Pelaksanaan penelitian ini mengambil lokasi di lembaga pendidikan kejuruan yaitu SMK Negeri 1 Pacitan yang beralamat di Jl. Let. Jend. Soeprapto No. 53 Kabupaten Pacitan propinsi Jawa 
Timur. Subyek penelitian dalam PTK ini adalah siswa kelas XI program studi Desain Komunikasi Visual yang berjumlah 22 siswa terdiri dari 16 siswa putra dan 6 siswa putri. Pelaksanaan penelitian disesuaikan dengan jadwal mata pelajaran produktif saat pembelajaran berlangsung. Waktu penelitian dilaksanakan pada semester gasal tahun pelajaran 2012/2013 dari bulan Juli sampai dengan bulan Desember tahun 2012 (6 bulan).

Untuk memecahkan masalah utama dan berdasarkan hasil analisis terhadap kondisi belajar siswa, maka disusun hipotesis tindakan yaitu metode demonstrasi sangat efektif dalam meningkatkan kompetensimenggambar desain poster pada siswa kelas XI program keahlian desain komunikasi visual SMK Negeri 1 Pacitan pada semester gasal tahun pelajaran 2012/2013.

Mengacu pada pendekatan PTK yang dipilih dan hipotesis tindakan seperti disampaikan, maka dibuat upaya pemecahan masalah dalam poster kegiatan sebagai berikut.

1. Observasi kelas untuk mengamati proses pembelajaran pada mata pelajaran produktif membuat desain poster.

2. Merumuskan metode pembelajaran yang sesuaiagar dapat dikembangkan menjadi suatu model pembelajaran yang aplikatif di kelas.

3. Mengimplementasikan model pembelajaran ke dalam kelas, melalui tahapan sebagai berikut:

a. Memberikan materi pelajaran mengenai desain poster dan jenisjenisnya serta teknik dalam pembuatan desain poster.

b. Memberi tugas kepada siswa untuk membuat suatu desain poster sesuai dengan tema yang telah ditetapkan oleh Guru mata diklat.

c. Memperlihatkan berbagai macam contoh media desain poster di kelas agar siswa mendapatkan konsep desain yang representative

d. Menerapkan metode demonstrasi untuk dapat meningkatkan kompetensi menggambar desain poster

e. Menilai karya desain poster

Prosedur penelitian meliputi kegiatan observasi dan refleksi awal dilanjutkan dengan pelaksanaan PTK. Kegiatan ini diawali dari siklus 1, dan dari hasil refleksi siklus 1 akan digunakan sebagai dasar dalam merencanakan tindakan siklus 2 .

Berdasarkan observasi sebagai refleksi awal pada tahun pelajaran sebelumnya, maka dapat disampaikan beberapa hal sebagai berikut:

1. Guru telah melaksanakan pembelajaran secara konvensional, namun ternyata kurang efektif, sebab dari hasil pengamatan sebagian besar siswa masing banyak yang tidak memperhatikan dan sebagian lagi hanya bergurau.

2. Hasil belajar produktif dan standart ketuntasan minimal belajar (SKMB) pada program studi desain komunikasi visual masih relatif rendah. Pada tahun pelajaran sebelumnya SKBM yang ditetapkan 70, sedangkan tuntutan perubahan dalam kurikulum pada program studi desain komunikasi visual yang sesuai dengan KTSP adalah 75 . Penentuan SKBM ini akan berpengaruh kepada semangat dan keseriusan belajar siswa. Apabila SKBM rendah, maka semangat dan keseriusan belajar siswa juga akan rendah, sedangkan bila 
SKBMnya tinggi siswa akan cenderung berjuang mengikutinya.

Instrumen yang digunakan dalam penelitian ini terdiri dari :

1. Silabus

Yaitu pedoman pembelajaran DKV yang mencakup Kompetensi Dasar, Indikator, Nilai Karakter, Materi Pokok Pembelajaran, Kegiatan Pembelajaran, Penilaian, Alokasi, Waktu dan Sumber Belajar.

2. Rencana Pelaksanaan Pemelajaran (RPP)

Yaitu administrasi atau seperangkat pembelajaran yang digunakan sebagai acuan guru dalam mengajar. Dalam penelitian ini Rencana Pelaksanaan Pemelajaran disusun sebanyak 2 siklus.

3. Lembar Kegiatan Siswa

Lembar kegiatan siswa ini dipergunakan untuk pengumpulan data siswa dalam proses pembelajaran

4. Lembar Observasi Kegiatan Belajar Mengajar

Lembar observasi pembelajaran untuk mengamati kemampuan guru dalam mengelola pembelajaran.

Adapun metode dalam pengumpulan data dalam penelitian ini yaitu :

1. Metode Wawancara

Metode wawancara adalah daftar pertanyaan yang dijawab langsung oleh para siswa dan atas jawaban tersebut kemudian diambil kesimpulan berkenaan dengan subyek yang diteliti. Metode ini dilaksanakan pada saat pembelajaran berlangsung.

2. Metode Dokumentasi

Yaitu peneliti melakukan pengambilan foto penelitian siswa kelas XI Program studi Desain Komunikasi
Visual pada saat proses pembelajaran berlangsung

\section{Metode Kepustakaan}

Yaitu peneliti mengumpulkan data dari buku kepustakaan yang ada di SMK Negeri Pacitan guna mendukung teori dalam peneitian ini. Untuk mengetahui sejauh mana pemahaman siswa kelas XI dalam menyerap mata pelajaran produktif membuat desain poster maka dalam analisis penelitian ini menggunakan rumus sederhana yang didukung dengan perhitungan program microsoft excel yaitu dengan membandingkan hasil pembelajaran berupa nilai rata-rata pada siklus 1 dan siklus 2 .

Analisis ini dihitung dengan menggunakan statistik sederhana yaitu:

a. Menilai ulangan atau tes formatif

Peneliti melakukan penjumlahan nilai yang diperoleh siswa, yang selan-jutnya dibagi dengan jumlah siswa yang ada di kelas tersebut sehingga diperoleh rata-rata tes formatif. Analisis peng-hitungan data yaitu dengan meng-gunakan program microsoft excel yang dapat menghitung secara tepat dan akurat. Dengan rumus sebagai berikut.

$$
\bar{X}=\frac{\sum X}{\sum N}
$$

Dimana $: \bar{X}=$ Nilai rata-rata

$\Sigma X \quad=$ Jumlah semua nilai siswa

$\Sigma \mathrm{N}=$ Jumlah semua siswa

b. Ketuntasan belajar

Untuk menghitung persentase ketuntasan belajar digunakan rumus sebagai berikut:

$$
P=\frac{\sum \text { Siswa yang tuntas belajar }}{\sum \text { Siswa }} \times 100 \%
$$


c. Lembar observasi

Lembar observasi pembelajaran digunakan rumus sebagai berikut:

$$
\bar{X}=\frac{P_{1}+P_{2}}{2}
$$

Dimana: $\mathrm{P}_{1}=$ pengamat 1 dan $\mathrm{P}_{2}=$ pengamat 2

Ukuran keberhasilan dalam Penelitian Tindakan Kelas ini adalah meningkatnya pemahaman dan hasil pembelajaran siswa kelas XI Program studi Desain Komunikasi Visual pada pembelajaran produktif menggambar desain poster baik secara individu maupun secara klasikal.

Indikator keberhasilan penelitian ini dikatakan berhasil apabila hasil tes menggambar desain poster sekurang kurangnya $90 \%$ siswa mengalami ketuntasan belajar. Dengan kata lain, 90\% seluruh siswa siswa mencapai kriteriake tuntasan minimal (KKM) yang ditetapkan oleh program studi yaitu 75 .

\section{PEMBAHASAN}

\section{Siklus 1}

\section{Perencanaan}

Pada tahap ini peneliti mempersiapkan perangkat pembelajaran yang terdiri dari rencana pelaksanaan Pelajaran, Contoh-contoh gambar poster, format penilaian, lembar observer dan alat-alat pengajaran yang mendukung.

\section{Kegiatan dan Pelaksanaan}

Pelaksanaan kegiatan belajar mengajar untuk siklus I dilaksanakan pada awal semester dua atau genap di Kelas XI dengan jumlah sampel 22 siswa. Dalam hal ini peneliti bertindak sebagai guru. Adapun proses belajar mengajar mengacu pada rencana pelajaran yang telah dipersiapkan. Pengamatan (observasi) dilaksanakan bersamaan dengan pelaksaaan belajar mengajar. Setiap siswa diberikan contoh gambar poster untuk digambar secara manual pada bidang gambar usuran A4. Selama proses pembelajaran peneliti mengamati dan memberi arahan dalam menggambar desain poster. Sedangkan observer mengamati dan mencatat proses pengajaran yang dilakukan oleh peneliti. Pelaksanaan pembelajaran berlangsung selama 7 jam dengan alokasi 1 jam ádalah 40 menit, istirahat 20 menit. Pada akhir proses belajar mengajar seluruh karya siswa dikumpulkan dan diberi penilaian. Masing-masing karya dievaluasi untuk ditunjukkan kekurangan dan kelemahan dalam menggambar desain poster sehingga siswa dapat memperbaiki pada tugas-tugas berikutnya. Dengan demikian peroses pembelajaran tersebut dapat diketahui tingkat keberhasilan siswa dalam proses belajar mengajar yang telah dilakukan.

Nilai rata-rata prestasi belajar siswa adalah 74,6 dan ketuntasan belajar mencapai $40 \%$ atau ada 9 siswa dari 22 siswa yang sudah tuntas belajar. Hasil ini menunjukkan bahwa pada siklus I ini ketuntasan belajar secara klasikal belum memenuhi standar nilai KKM yaitu 75 untuk mata pelajaran produktif.

Sedangkan penilaian dari 2 observer yang merupakan rekan guru produktif program studi desain komunikasi visual setelah melaksanakan pengamatan selama pembelajaran pada sklus 1 diperoleh data sebagai berikut.

\section{Refleksi}

Dalam pelaksanaan kegiatan belajar mengajar diperoleh data hasil pengamatan sebagai berikut: 
1) Guru kurang dalam memotivasi siswa

2) Guru kurang baik dalam pengelolaan waktu

3) Siswa kurang begitu antusias selama pembelajaran berlangsung

Refisi

Pelaksanaan kegiatan belajar mengajar pada siklus 1 ini masih terdapat kekurangan terutama dalam memotivasi siswa dan pengelolaan waktu serta penampilan didepan kelas.

\section{Siklus 2}

\section{Perencanaan}

Tahap ini peneliti mempersiapkan perang-kat pembelajaran yang terdiri dari rencana pelaksanaan Pelajaran, Contohcontoh gambar poster, format penilaian, lembar observer dan alat-alat pengajaran yang mendukung.

\section{Kegiatan dan Pelaksanaan}

Pelaksanaan kegiatan belajar mengajar untuk siklus 2 dilaksanakan pada awal semester genap di Kelas XI dengan jumlah sampel 22 siswa. Dalam hal ini peneliti bertindak sebagai guru. Adapun proses belajar mengajar mengacu pada rencana pelajaran yang telah dipersiapkan. Pengamatan (observasi) dilaksanakan bersamaan dengan pelaksaaan belajar mengajar.

Selama proses pembelajaran peneliti memberi contoh bagaimana menggambar desain poster dengan menggunakan metode demonstrasi yaitu peneliti secara langsung membuat desain poster pada program corel draw $x 6$ melalui layar LCD di depan kelas. Siswa memperhatikan dengan seksama untuk kemudian setelah diadakan demonstrasi siswa menanyakan hal-hal yang belum jelas dan guru mengulangi lagi mendemonstrasikan pembuatan desain poster sehingga siswa menjadi jelas dan mulai membuat tugas membuat desain poster dengan baik dan sesuai kaidah pembuatan poster yang estetis dan menarik.

Selama proses mengerjakan tugas membuat desain poster dengan tema yang telah ditentukan, peneliti mengamati, mengawasi dan tetap memberi bimbingan kepada siswa untuk cermat, teliti dan tekun dalam membuat desain poster. Setelah selesai peneliti menerima hasil karya seluruh siswa, memberi evaluasi dan apresiasi serta penilaian secara langsung sehingga seluruh siswa mengetahui hasil penilaian yang diberikan oleh guru.

Nilai rata-rata prestasi belajar siswa adalah 81,88 dan ketuntasan belajar mencapai $100 \%$ atau secara keseluruhan 22 siswa sudah tuntas belajar.

\section{Refleksi}

Dalam pelaksanaan kegiatan belajar mengajar diperoleh data hasil pengamatan sebagai berikut:

1) Guru sudah sangat baik dalam memotivasi siswa dan dalam menyampaikan tujuan pembelajaran

2) Guru juga sudah sangat baik dalam pengelolaan waktu.

3) Siswa sangat antusias selama pembelajaran berlangsung.

\section{Refisi}

Pelaksanaan kegiatan belajar mengajar pada siklus 2 menunjukkan peningkatan prestasi belajar yang sangat signifikan sehingga pembelajaran sudah memenuhi target nilai KKM. 


\section{KESIMPULAN}

Dari hasil penelitian yang telah dilaksanakan setelah menggunakan metode demonstrasi, kompetensi menggambar desain poster pada siswa dapat meningkat secara signifikan yang dibuktikan dari hasil karya desain yang sudah sesuai dengan standar penilaian.

Pada siklus 1, penilaian karya desain poster belum menunjukkan karya yang sesuai dengan kriteria penilaian dari berbagai unsur sehingga diperlukan suatu metode pembelajaran untuk meningkatkan kemampuan desain poster tersebut. Nilai rata-rata prestasi belajar siswa adalah 74,6 dan ketuntasan belajar mencapai $40 \%$ atau ada 9 siswa dari 22 siswa yang sudah tuntas belajar. Hasil ini menunjukkan bahwa pada siklus 1 ini ketuntasan belajar secara klasikal belum memenuhi standar nilai KKM yaitu 75 untuk mata pelajaran produktif.

Pada siklus 2, kemampuan siswa dalam membuat desain poster dengan berbagai tema memlalui metode demonstrasi sudah menunjukkan peningkatan yang sangat memuaskan baik dilihat dari unsur komposisi, tata letak, pewarnaan maupun tipografi.

Nilai rata-rata prestasi belajar siswa adalah 81,88 dan ketuntasan belajar mencapai $100 \%$ atau secara keseluruhan 22 siswa sudah tuntas belajar. Dengan metode demonstrasi sekaligus dapat meningkatkan motivasi belajar siswa yang ditunjukkan dengan rata-rata jawaban siswa yang menyatakan bahwa siswa tertarik dan berminat dengan model pembelajaran pendekatan metode demonstrasi sehingga mereka menjadi termotivasi untuk meningkatkan kompetensi menggambar desain poster dengan lebih baik.

\section{Saran-Saran}

Dari hasil penelitian yang diperoleh dan dari uraian sebelumnya agar proses pembelajaran desain komunikasi visual lebih efektif dan lebih memberikan hasil yang optimal maka beberapa saran dapat penulis sampaikan yaitu untuk melaksanaan pembelajaran pendekatan metode demonstrasi ternyata memerlukan persiapan yang cukup matang, sehingga guru harus mampu menentukan atau memilih topik yang benar-benar bisa diterapkan dengan cara pembelajaran pendekatan metode demonstrasi dalam proses belajar sehingga diperoleh hasil yang optimal.

\section{DAFTAR PUSTAKA}

Arikunto, Suharsimi, 2002. Prosedur Penelitian Suatu Pendekatan Praktek. Jakarta: Rineka Cipta.

Djamarah, Syaiful Bahri. 2002. Strategi Belajar Mengajar. Jakarta: Rineksa Cipta

Bahan Ajar Dasar Kekriaan untuk SMK, 1998., Menggambar desain poster Geometris, Direktorat Pendidikan Menengah Kejuruan, Dep. P dan K http://belajarsemangatz.blogspot.com/2012 /10/pengertian-poster.html

Madya, Suwarsih, 2006, Teori Dan Praktik Penelitian Tindakan (Action Research), Bandung: Alfabeta.

Moleong, J, Lexy, 2002, Metodologi penelitian kualitatif, Bandung: Remaja, Rosdakarya.

Peraturan Menteri Pendidikan Nasional Nomor 41 Tahun 2007 tentang Standar Proses 